\title{
Electron Transfer Reduction of Acetylene by Catalysis of Partially $p$-Mercaptomethyl Substituted Polystyrene- Molybdenum(IV) Complexes in Protic Solvent
}

\author{
Nobuki OGUNI, Shogo SHIMAZU, \\ Yasuhiro IwAmoTo, and Akira NAKAMURA \\ Department of Macromolecular Science, Faculty of Science, Osaka University, \\ 1-1 Machikaneyama, Toyonaka, Osaka 560, Japan.
}

(Received December 15, 1980)

\begin{abstract}
Molybdenum(IV) complexes supported on partially $p$-mercaptomethyl substituted cross-linked polystyrene were prepared. A binary system of the above molybdenum complexes and ferredoxin model compound, $\left[\mathrm{Fe}_{4} \mathrm{~S}_{4}(\mathrm{SPh})_{4}\right]^{2-}$, has excellent catalytic activity for the reduction of acetylene, compared to the corresponding unsupported molybdenum complexes. The reduction and reductive cleavage of dinitrogen were also investigated as a nitrogenase model reaction.

KEY WORDS Molybdenum(IV) Complex / Reduction of Acetylene / Reduction of Dinitrogen / Catalysis of Polymer-Metal Complex /
\end{abstract}

The MoFe protein components of Clostridium pasteurianum $^{1}$ and Azotobacter vinelandii $(\mathrm{Az} . \mathrm{V})^{2}$ nitrogenase and the FeMo cofactor (FeMo-co) ${ }^{2}$ from Az. V were isolated; their K-edge X-ray absorption fine structure (EXAFS) analyses indicated that the molybdenum is coordinated by three or four organic and inorganic sulfides. The FeMoco has $c a .8 \%$ activity of native nitrogenase for the selective reduction of acetylene to ethylene with $\mathrm{NaBH}_{4}{ }^{3}$ In an attempt to find a functional enzyme model, the $\mu$-dioxodi(oxomolybdenum)(V) complex coordinated by L-cysteine ligand, $\left[\mathrm{Mo}_{2} \mathrm{O}_{4}(\mathrm{cys})_{2}\right]^{2-}$, was examined as a component of catalyst in nitrogenase model reaction for the reduction of acetylene and dinitrogen. ${ }^{4-6}$ Recently, an oxomolybdenum complex supported on insulin was found to have catalytic activity for the reductive cleavage of dinitrogen. ${ }^{7}$ The activity of this polypeptide-Mo complex was reported to be definitely higher than that observed for the Mo complexes of cysteine or other simple organic thiols. In our previous studies, ${ }^{8}$ we have found that L-cysteine-containing copolypeptide-Mo(V) complexes had a higher catalytic activity than the corresponding non-supported $\mathrm{Mo}(\mathrm{V})$ complexes for the reduction of phenylacetylene and azobenzene. This high activity of
polypeptide-Mo complexes was tentatively concluded as a result of preventing deactivation by the aggregation of a reduced catalytically active molybdenum species. Similar effect is significant for catalysis by Mo complexes supported on crosslinked polystyrene. This report deals with the catalytic reduction of acetylene with $\mathrm{NaBH}_{4}$ by a binary system of $\mathrm{Mo}(\mathrm{IV})$ complexes of partially $p$ mercaptomethyl substituted polystyrene and ferredoxin model compound, $\left[\mathrm{Fe}_{4} \mathrm{~S}_{4}(\mathrm{SPh})_{4}\right]^{2-}$. Reduction of dinitrogen was also examined using a catalyst system best suited for the acetylene reduction.

\section{EXPERIMENTAL}

\section{Instrumentation}

Visible and UV spectra were taken with a JASCO-UVIDEC 5A spectrometer at room temperature. The identification and quantitative determination of the products in the reduction of acetylene were made by a Yanaco gas chromatograph model G80 equipped with Porapak $\mathrm{N}$ as column packing material at $40-160^{\circ}$. NMR spectra were taken with a Varian XL-100. 


\section{Reagents}

Tetrahydrofuran (THF) was distilled from sodium benzophenone ketyl under an argon atmosphere. $n$-Hexane, diethylether, petroleum ether, methanol, and ethanol were purified by conventional methods.

\section{Tetrakis (dimethylamino) molybdenum(IV)}

This compound was prepared by the method reported by Bradley et al. ${ }^{9} \mathrm{Mo}\left(\mathrm{NMe}_{2}\right)_{4}(0.02 \mathrm{~mol})$ was obtained by the reaction of $\mathrm{MoCl}_{5}(0.22 \mathrm{~mol})$ with $\mathrm{LiNMe}_{2}(1.1 \mathrm{~mol})$. The product, an airsensitive purple solid, was purified by sublimation at $70^{\circ}$ under $1 \times 10^{-3} \mathrm{mmHg}$.

\section{Hexakis (dimethylamido)dimolybdenum(III)}

The method reported by Chisholm et al. ${ }^{10}$ was used. The residue, from which $\mathrm{Mo}\left(\mathrm{NMe}_{2}\right)_{4}$ was completely distilled, was heated to $100-120^{\circ}$ under $0.5 \times 10^{-4} \mathrm{mmHg}$ for $6 \mathrm{~h}$ to afford pale yellow crystals of $\mathrm{Mo}_{2}\left(\mathrm{NMe}_{2}\right)_{6}$ sublimed at the cooled part. The crude air-sensitive product was purified by resublimation. Anal. Calcd. for $\mathrm{C}_{12} \mathrm{H}_{36} \mathrm{~N}_{6} \mathrm{Mo}_{2}$ : C, $31.58 \%$; H, 7.95\%; N, 18.42\%. Found C, 30.27\%; $\mathrm{H}, 7.69 \%$; N, $18.64 \%$.

\section{Preparation of Partially p-Chloromethyl-Substituted Cross-Linked Polystyrene}

$p$-Chloromethylated polystyrene $(17 \mathrm{~g})$ of the product of Peptide Institute (divinylbenzene $2 \%$, 100-200 mesh, Cl: $1.34 \mathrm{mmol} \mathrm{g}^{-1}$ ) was suspended in THF $(120 \mathrm{ml})$ under an argon atmosphere. To this suspension was added the required amount of $n$ butyllithium in hexane with stirring for $3 \mathrm{~h}$ at room temperature. Water was added to the suspension and the polymer was filtered and washed with water and then ethanol. By this method, two samples of different $p$-chloromethyl group content were prepared. Anal. Found for polystyrene No. 1 (a starting polystyrene): C, $88.90 \% ; \mathrm{H}, 7.55 \% ; \mathrm{Cl}, 3.59 \%$. Found for polystyrene No. 2: C, $89.62 \% ; \mathrm{H}, 7.69 \%$; $\mathrm{Cl}, 2.72 \%$. Found for polystyrene No. 3: C, $89.47 \%$; $\mathrm{H}, 7.67 \%$; Cl. $2.36 \%$.

\section{p-Mercaptomethyl-Substituted Polystyrene}

A mixture of partially $p$-chloromethylated polystyrene in ethanol and the required amount of thiourea (1.5 eq. of $p$-chloromethyl groups in polystyrene) in water were refluxed for $12 \mathrm{~h}$. After cooling to room temperature, the product was hydrolyzed by the addition of aq. $\mathrm{NaOH}$ ( 2 eq. of thiourea), and the suspension was refluxed for $3 \mathrm{~h}$. The reaction mixture was cooled below $5^{\circ} \mathrm{C}$ and acidified to a $\mathrm{pH}$ of 2 with $6 \mathrm{~N}$ sulfuric acid. The polymer was separated by filtration, washed with water and then with ethanol. Anal. Found for polystyrene No. 1: C, $88.61 \% ; \mathrm{H}, 7.71 \% ; \mathrm{S}, 2.78 \%$. Found for polystyrene No. 2: C, $88.61 \%$; H, $7.82 \%$; S, $1.97 \%$. Found for polystyrene No. 3: C, $88.81 \%$; H, $7.83 \%$; S, $1.49 \%$ (conversion, 85\%).

Ligand Substitution Reaction of $\mathrm{Mo}\left(\mathrm{NMe}_{2}\right)_{4}$ with 2Propanethiol

To $\mathrm{Mo}\left(\mathrm{NMe}_{2}\right)_{4}\left(3.9 \times 10^{-2} \mathrm{mmol}\right)$ in THF $(20 \mathrm{ml})$ was added 2-propanethiol $\left(1.6 \times 10^{-1}\right.$ mmol) with stirring under argon atmosphere. The solution was shaken at room temperature for $3 \mathrm{~h}$; the THF was then removed by distillation under reduced pressure. The residual reddish brown solid was insoluble in THF and other organic solvents.

\section{Preparation of Partially p-Mercaptomethylated} Polystyrene-Mo(IV) Complexes

$\mathrm{Mo}\left(\mathrm{NMe}_{2}\right)_{4}$ (2 eq. of thiol groups in polymer) was added to a suspension of partially $p$ mercaptomethylated polystyrene in THF under an argon atmosphere. The mixture was stirred at room temperature for $24 \mathrm{~h}$, and then the polymerMo(IV) complex was separated by filtration and washed with THF so as to remove any unreacted Mo complexes. Anal. Mo, Found for the complex with polystyrene No. 1: $4.46 \%$; for polystyrene No. 2: $3.18 \%$; for polystyrene No. $3: 2.58 \%$. Quantitative determination of Mo was conducted according to the method reported by Pribil et al. ${ }^{11}$

Reduction of Acetylene by Catalysis of Partially pMercaptomethylated Polystyrene-Mo(IV) Complex with $\mathrm{NaBH}_{4}$

The polystyrene-Mo(IV) complex $\left(1.0 \times 10^{-4}\right.$ mmol to Mo) and ferredoxin model complex, $\left[\mathrm{Fe}_{4} \mathrm{~S}_{4}(\mathrm{SPh})_{4}\right]\left[\mathrm{N}-n \mathrm{Bu}_{4}\right]_{2} \quad\left(1.0 \times 10^{-4} \mathrm{mmol}\right)$ were mixed in THF $(4.6 \mathrm{ml})$ under an argon atmosphere. $\mathrm{NaBH}_{4}(7.9 \mathrm{mmol})$ as a reducing agent was then added to the above solution. After replacing argon with acetylene in a reaction vessel ethanol $(7.6 \mathrm{ml})$ and methanol $(3.0 \mathrm{ml})$ were added to the above mixture, and the solution was stirred vigorously in a water bath kept at $30^{\circ} \mathrm{C}$. Reaction products in vapor and in solution taken out with a syringe were 
quantitatively analyzed by GLC at a certain time interval of the reaction.

Reduction and Reductive Cleavage of Dinitrogen by Catalysis of the Polystyrene-Mo(IV) Complex with $\mathrm{NaBH}_{4}$

Polystyrene-Mo(IV) complex $\left(1.97 \times 10^{-2} \mathrm{mmol}\right.$ to $\mathrm{Mo})$ and $\left[\mathrm{Fe}_{4} \mathrm{~S}_{4}(\mathrm{SPh})_{4}\right]\left[\mathrm{N}-n \mathrm{Bu}_{4}\right]_{2}\left(1.97 \times 10^{-2}\right.$ mmol) were mixed in THF $(4.6 \mathrm{ml})$ under an argon atmosphere. Then, $\mathrm{NaBH}_{4}(2.0 \mathrm{mmol})$ was added to the above solution. After replacing argon with oxygen-free nitrogen in a reaction vessel, a mixture of ethanol $(7.4 \mathrm{ml})$ and methanol $(3.0 \mathrm{ml})$ was added to the mixture, and under a circulation system dinitrogen was introduced into the vigorously stirred catalyst solution in a water bath kept at $30^{\circ} \mathrm{C}$. At hourly intervals, $\mathrm{NaBH}_{4}(2.0 \mathrm{mmol})$ was added to the solution over a period of $4 \mathrm{~h}$. The reaction mixture was completely distilled under reduced pressure into aq. $3 \mathrm{~N} \mathrm{H}_{2} \mathrm{SO}_{4}$ stored in a reservoir. The distillates from this mixture in aq. $\mathrm{H}_{2} \mathrm{SO}_{4}$ were removed under reduced pressure, and the residue was alkalized by aq. $3 \mathrm{~N} \mathrm{NaOH}$, followed by complete distillation into a trap cooled by liquid nitrogen. The distillates were divided into equal amounts of two portions, each whose quantity of hydrazine and ammonia was determined by colorimetry with $p$-dimethylaminobenzaldehyde and indophenol methods, ${ }^{12}$ respectively. The reaction product with hydrazine had an absorption maximum at $475 \mathrm{~nm}$, and that with ammonia had one at $620 \mathrm{~nm}$. Reduction of dinitrogen by a binary system of random copolypeptide ${ }^{8}-\mathrm{Mo}\left(\mathrm{NMe}_{2}\right)_{4}$ and $\left[\mathrm{Fe}_{4} \mathrm{~S}_{4}(\mathrm{SPh})_{4}\right]^{2-}$ was carried out by a method similar to that for the polystyrene- $\mathrm{Mo}\left(\mathrm{NMe}_{2}\right)_{4}$ systems.

\section{RESULTS AND DISCUSSION}

\section{Preparation of Catalyst}

In view of the importance of low-valent Mo species without oxo ligands in the FeMo-co, we looked for suitable catalyst precursors containing low-valent Mo species with readily replaceable ligands. Tetrakis (dimethylamido)-molybdenum$(\mathrm{IV})^{9}$ was found to be a useful catalyst precursor, capable of reacting with alcohols and thiols without any change in the formal oxidation state. The following model reaction with simple organic thiol compounds was examined first. Thus, 1-

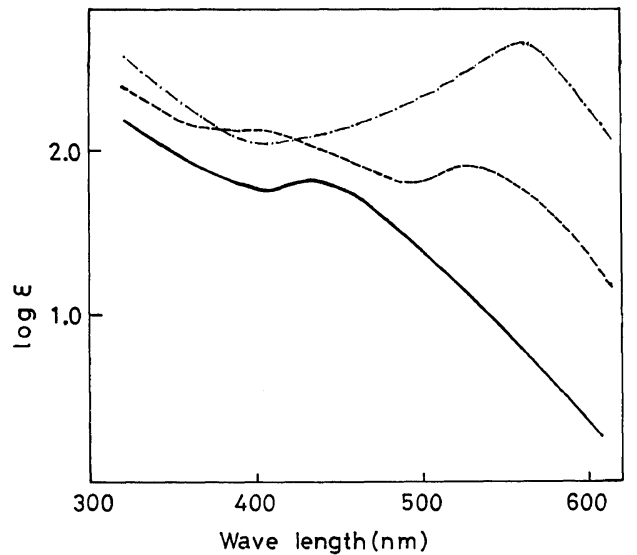

Figure 1. Electronic absorption spectra of $\mathrm{Mo}\left(\mathrm{NMe}_{2}\right)_{4}$ (-) and the reaction products of $\mathrm{Mo}\left(\mathrm{NMe}_{2}\right)_{4}$ with 1propanethiol (---) and phenylmethanethiol (-.-.-) in THF.

propanethiol and phenylmethanethiol were added to $\mathrm{Mo}\left(\mathrm{NMe}_{2}\right)_{4}$ in THF in a molar ratio of $4: 1$ and the absorption spectra of $\mathrm{Mo}\left(\mathrm{NMe}_{2}\right)_{4}$ and of the reaction mixtures of $\mathrm{Mo}\left(\mathrm{NMe}_{2}\right)_{4}$ with the above thiols were compared in order to detect the reaction. $\mathrm{Mo}\left(\mathrm{NMe}_{2}\right)_{4}$ had a peak at $435 \mathrm{~nm}(\varepsilon=65.4)$. The reaction mixture with 1-propanethiol had two peaks at $404 \mathrm{~nm}(\varepsilon=122)$ and $532 \mathrm{~nm}(\varepsilon=73.8)$ and the one with phenylmethanethiol had a peak at $560 \mathrm{~nm}$ $(\varepsilon=457)$ (Figure 1). By analogy with the formation of the hexacoordinate molybdenum(IV) complex, $\mathrm{Mo}(\mathrm{OR})_{4} \mathrm{~L}_{2} \quad\left(\mathrm{~L}=\mathrm{NHMe}_{2}\right)$, by the reaction of $\mathrm{Mo}\left(\mathrm{NMe}_{2}\right)_{4}$ with trimethylsilanol, ${ }^{10}$ such compounds as $\mathrm{Mo}(\mathrm{SR})_{4}\left(\mathrm{NHMe}_{2}\right)_{2}$, may be postulated as a solution reaction products. However, attempts to isolate these compounds failed, giving only polymeric associates of $\left[\mathrm{Mo}(\mathrm{SR})_{4}\right]_{n}$ insoluble in THF. Molybdenum alkoxide, $\mathrm{Mo}(\mathrm{OR})_{4}$, oligomerizes by means of alkoxide groups serving as $\mu$-alkoxo ligands. ${ }^{10}$ Since a hexa-coordinated prismatic tetrathiolato $\mathrm{Mo}(\mathrm{IV})$ complex, $\mathrm{Mo}\left(\mathrm{SCH}_{2} \mathrm{CH}_{2} \mathrm{SCH}_{2}\right.$ $\left.\mathrm{CH}_{2} \mathrm{~S}\right)_{2}$, was reported, ${ }^{13}$ the tetrathiolato complex obtained from $\mathrm{Mo}\left(\mathrm{NMe}_{2}\right)_{4}$ probably has a hexacoordinate structue similar to bridging thiolato ligands. On the basis of the above

$$
\begin{aligned}
& \mathrm{Mo}\left(\mathrm{NMe}_{2}\right)_{4}+4 \mathrm{ROH} \longrightarrow \\
& \quad \mathrm{Mo}(\mathrm{OR})_{4}\left(\mathrm{NHMe}_{2}\right)_{2} \longrightarrow\left[\mathrm{Mo}(\mathrm{OR})_{4}\right]_{n} \\
& \mathrm{Mo}\left(\mathrm{NMe}_{2}\right)_{4}+4 \mathrm{RSH} \longrightarrow \\
& \quad \mathrm{Mo}(\mathrm{SR})_{4}\left(\mathrm{NHMe}_{2}\right)_{2} \longrightarrow\left[\mathrm{Mo}(\mathrm{SR})_{4}\right]_{n}
\end{aligned}
$$


ligand exchange reaction, we prepared the molybdenum(IV) complexes of partially $p$ mercaptomethyl substituted cross-linked polystyrene (abridged as PS-SH). The ratio of molybdenum to thiolato groups in the PS-SH molybdenum complexes was calculated from the values of the quantitative analysis of molybdenum metal and sulfur atom. These ratios were 0.536 for polystyrene No. 1, 0.540 for polystyrene No. 2, and 0.579 for polystyrene No. 3 . These results indicated that one molybdenum metal coordinated with two thiolato groups on the average, in spite of variable $p$ mercaptomethyl substitutions. The observed ligandto-metal ratio $(=2)$ is supported in the reaction of $\left[\mathrm{RhCl}\left(\mathrm{C}_{8} \mathrm{H}_{12}\right)\right]_{2}$ with cross-linked polystyrene bearing a variety of diphenylphosphine substitutions, where two moles of cyclooctadiene are displaced to give a product in which rhodium is coordinated by two phosphine ligands of the polymer. ${ }^{19}$ A recent EXAFS study of cross-linked polystyrene-supported $\mathrm{Rh}(\mathrm{I})$ catalyst revealed a bidentate structure similar to that mentioned above. ${ }^{20}$

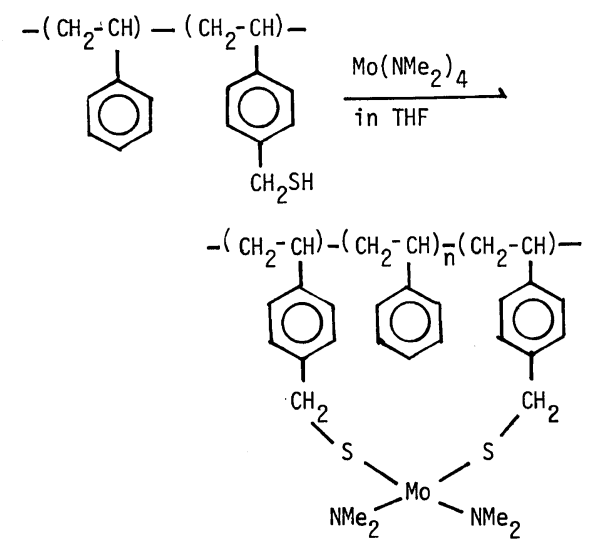

Reduction of Acetylene with $\mathrm{NaBH}_{4}$ by Catalysis of a Mixed System of $\mathrm{Mo}\left(\mathrm{NMe}_{2}\right)_{4}$, Phenylmethanethiol and Ferredoxin Model Compound, $\left[\mathrm{Fe}_{4} \mathrm{~S}_{4}(\mathrm{SPh})_{4}\right]^{2-}$

Catalytic activity and selectivity in the reduction of acetylene was examined for the catalyst system, $\left.\mathrm{Mo}(\mathrm{NMe})_{2}\right)_{4} / \mathrm{PhCH}_{2} \mathrm{SH}$. The relative amount of phenylmethanethiol varied from $1: 1$ to $1: 4$. The results of the reduction of acetylene are summarized in Table I. The main product from reduction was ethylene and small amounts of butadiene and ethane were also produced. The addition of phenylmethanethiol to the system decreased the formation of ethylene and increased the formation of butadiene. Therefore, the incremental addition of thiols caused the butadiene/ethylene ratio to increase steadily. The turnover number decreased by the addition of phenylmethanethiol. Stiefel et al. reported that on reducing acetylene in protic media by catalysis of $\left[\mathrm{Mo}_{2} \mathrm{O}_{4}(\mathrm{cys})_{2}\right]^{2-}$, the ratio of butadiene to ethylene varied, depending on the buffer solution used, while role of the buffer was obscure. ${ }^{14}$

The following points are suggested on the basis of the above results: 1) Since low-valent Mo(III or IV) thiolato complexes have in general insoluble polynuclear structures, $\left[\mathrm{Mo}(\mathrm{SR})_{3} \text { or } \mathrm{Mo}(\mathrm{SR})_{4}\right]_{n}$, involving bridging thiolato groups, lower activity on addition of thiols is probably due to the aggregation of molybdenum complexes through thiolato groups. 2) Product selectivity may be due to the covalency of Mo-L ( $\mathrm{L}=$ ligand) bonds at the active sites, since the covalency at the Mo-thiolate bonding is considered to cause the Mo- $\left(\eta^{2}\right.$-acetylene $)$ bond to become stronger and less ionic and insertion of further molecule of actylene prior to the protolysis to ethylene may be lessened.

In the preparation of $\mathrm{Mo}\left(\mathrm{NMe}_{2}\right)_{4}$ by the reaction of $\mathrm{MoCl}_{5}$ with $\mathrm{Me}_{2} \mathrm{NLi}$, a $\mathrm{Mo}$ (III) complex, $\left(\mathrm{Me}_{2} \mathrm{~N}\right)_{3} \mathrm{Mo} \equiv \mathrm{Mo}\left(\mathrm{NMe}_{2}\right)_{3}$, was obtained as crystals. ${ }^{15}$ This low-valent molybdenum complex and its alkoxy derivatives have been investigated in detail. ${ }^{15}$ In the catalytic reduction of acetylene with $\mathrm{Mo}\left(\mathrm{NMe}_{2}\right)_{4}$, Mo-Mo multiple bond formation is expected. Thus, we examined how aggregation of a molybdenum complex affects catalytic activity by using a well-defined binuclear molybdenum complex, $\mathrm{Mo}_{2}\left(\mathrm{NMe}_{2}\right)_{6}$, as the catalyst. The results of acetylene reduction are shown in Table I and Figure 2. The catalytic activity of $\mathrm{Mo}_{2}\left(\mathrm{NMe}_{2}\right)_{6}$ in acetylene reduction was considerably lower than that of the mononuclear complex, $\mathrm{Mo}\left(\mathrm{NMe}_{2}\right)_{4}$. Thus, it was concluded that Mo-Mo multiple bond formation causes a lowering of catalytic activity.

\section{Reduction of Acetylene with $\mathrm{NaBH}_{4}$ by Catalysis of a Mixed System of p-Mercaptomethylated Poly- styrene-Mo(IV) Complexes and Ferredoxin Model Complexes, $\left[\mathrm{Fe}_{4} \mathrm{~S}_{4}(\mathrm{SPh})_{4}\right]^{2-}$}

In order to prevent aggregation of molybdenum complexes, we used the partially $p$-mercaptomethyl substituted cross-linked polystyrene as a ligand. The results of the catalysis of the reduction of acetylene are shown in Table II and Figure 3. The catalytic 


\section{Catalysis of Polystyrene-Supported Molybdenum Complex}

Table I. Selectivity and activity of catalysis by molybdenum complexes for acetylene reduction with $\mathrm{NaBH}_{4}{ }^{\mathrm{a}}$

\begin{tabular}{|c|c|c|c|c|c|c|}
\hline \multirow{4}{*}{$\begin{array}{c}\text { Catalyst systems } \\
\left(+\left[\mathrm{Fe}_{4} \mathrm{~S}_{4}(\mathrm{SPh})_{4}\right]^{2-}\right)\end{array}$} & \multirow{4}{*}{$\frac{\text { Time }}{\mathrm{h}}$} & \multirow{4}{*}{$\frac{\text { Conversion }}{\%}$} & \multicolumn{3}{|c|}{ Product } & \multirow{2}{*}{ Turnover number } \\
\hline & & & \multirow{3}{*}{$\frac{\text { Ethylene }}{\%}$} & \multirow{3}{*}{$\frac{\text { Butadiene }}{\%}$} & \multirow{3}{*}{$\begin{array}{c}\text { Ethane } \\
\%\end{array}$} & \\
\hline & & & & & & $\mathrm{mol} / \mathrm{mol}[\mathrm{Mo}] \mathrm{min}^{-1}$ \\
\hline & & & & & & \\
\hline $\mathrm{Mo}\left(\mathrm{NMe}_{2}\right)_{4}$ & 5 & 28.0 & 18.5 & 4.0 & 1.5 & 0.19 \\
\hline $\mathrm{Mo}\left(\mathrm{NMe}_{2}\right)_{4}+\mathrm{C}_{6} \mathrm{H}_{5} \mathrm{CH}_{2} \mathrm{SH}$ & 5 & 7.6 & 3.3 & 1.7 & 2.0 & 0.05 \\
\hline $\mathrm{Mo}\left(\mathrm{NMe}_{2}\right)_{4}+2 \mathrm{C}_{6} \mathrm{H}_{5} \mathrm{CH}_{2} \mathrm{SH}$ & 5 & 22.2 & 5.4 & 8.7 & 2.1 & 0.15 \\
\hline $\mathrm{Mo}\left(\mathrm{NMe}_{2}\right)_{4}+3 \mathrm{C}_{6} \mathrm{H}_{5} \mathrm{CH}_{2} \mathrm{SH}$ & 5 & 22.0 & 5.2 & 5.5 & 2.8 & 0.15 \\
\hline $\mathrm{Mo}\left(\mathrm{NMe}_{2}\right)_{4}+4 \mathrm{C}_{6} \mathrm{H}_{5} \mathrm{CH}_{2} \mathrm{SH}$ & 5 & 14.6 & 0.1 & 7.1 & 0.3 & 0.10 \\
\hline $\mathrm{Mo}_{2}\left(\mathrm{NMe}_{2}\right)_{6} *$ & 5 & 3.6 & 3.0 & 0.3 & 0.3 & 0.04 \\
\hline
\end{tabular}

a Conditions: acetylene, $3.93 \mathrm{mmol} ; \mathrm{NaBH}_{4}, 7.9 \mathrm{mmol}$; catalyst, $0.0197 \mathrm{mmol}(\mathrm{Mo})$, ratio of $\mathrm{Fe} / \mathrm{Mo}=4$; temperature, $30^{\circ} \mathrm{C}$; solvent, EtOH-THF-MeOH $(2.5: 1.5: 1)$ (total $\left.15.5 \mathrm{ml}\right)(* 8: 4.5: 2$, total $14.5 \mathrm{ml})$.

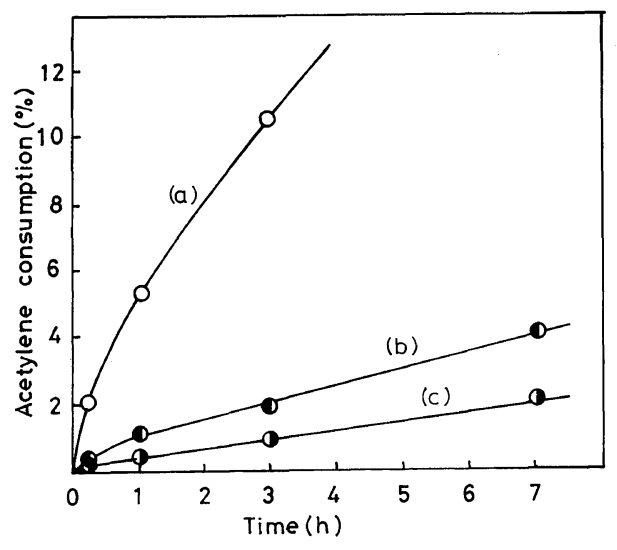

Figure 2. Acetylene reduction by catalysis of (a) $\mathrm{Mo}\left(\mathrm{NMe}_{2}\right)_{4}-\left[\mathrm{Fe}_{4} \mathrm{~S}_{4}(\mathrm{SPh})_{4}\right]^{2-}$ (O), (b) $\mathrm{Mo}_{2}\left(\mathrm{NMe}_{2}\right)_{6}$ $\left[\mathrm{Fe}_{4} \mathrm{~S}_{4}(\mathrm{SPh})_{4}\right]^{2-}$ (O), and (c) $\mathrm{Mo}_{2}\left(\mathrm{NMe}_{2}\right)_{6} \quad$ (O). Experimental conditions are the same as in Table I.

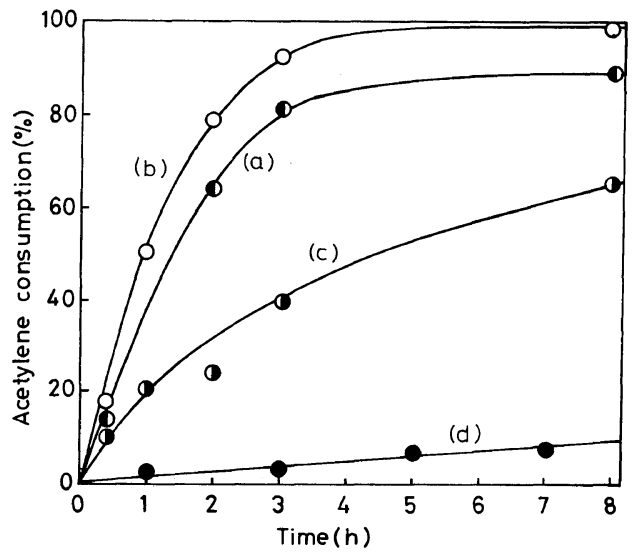

Figure 3. Acetylene reduction by catalysis of a binary system of $\left[\mathrm{Fe}_{4} \mathrm{~S}_{4}(\mathrm{SPh})_{4}\right]^{2-}$ and (a) polystyrene No. $1 / \mathrm{Mo}\left(\mathrm{NMe}_{2}\right)_{4}(\mathrm{O})$, (b) polystyrene No. $2 / \mathrm{Mo}\left(\mathrm{NMe}_{2}\right)_{4}$ (O), (c) polystyrene No. 3/Mo(NMe $)_{4}$ (O), (d) $\mathrm{Mo}\left(\mathrm{NMe}_{2}\right)_{4}(\mathrm{O})$. Experimental conditions are the same as in Table II.

Table II. Selectivity and activity of catalysis by the $p$-mercaptomethyl polystyrene-molybdenum complex for acetylene reduction with $\mathrm{NaBH}_{4}{ }^{\mathrm{a}}$

\begin{tabular}{|c|c|c|c|c|c|}
\hline \multirow{4}{*}{ Catalyst systems } & \multirow{4}{*}{$\frac{\text { Conversion }}{\%}$} & \multicolumn{3}{|c|}{ Product } & \multirow{4}{*}{$\frac{\text { Turnover number }}{\mathrm{mol} / \mathrm{mol}[\mathrm{Mo}], \mathrm{min}^{-1}}$} \\
\hline & & \multirow{3}{*}{$\frac{\text { Ethylene }}{\%}$} & \multirow{3}{*}{$\frac{\text { Butadiene }}{\%}$} & \multirow{3}{*}{$\begin{array}{c}\text { Ethane } \\
\%\end{array}$} & \\
\hline & & & & & \\
\hline & & & & & \\
\hline $\begin{array}{l}\text { Polystyrene No. } 2 / \mathrm{Mo}\left(\mathrm{NMe}_{2}\right)_{4} \\
\text { Polystyrene No. } 2 / \mathrm{Mo}\left(\mathrm{NMe}_{2}\right)_{4}\end{array}$ & 9.2 & 6.7 & 1.0 & 0.5 & 0.20 \\
\hline $\begin{array}{l}\quad+\left[\mathrm{Fe}_{4} \mathrm{~S}_{4}(\mathrm{SPh})_{4}\right]^{2-} \\
\text { Polystyrene No. } 2 / \mathrm{Mo}\left(\mathrm{NMe}_{2}\right)\end{array}$ & 94.2 & 77.5 & 1.8 & 13.1 & 2.40 \\
\hline$+2\left[\mathrm{Fe}_{4} \mathrm{~S}_{4}(\mathrm{SPh})_{4}\right]^{2-}$ & 99.8 & 54.6 & 5.6 & 34.0 & 2.62 \\
\hline
\end{tabular}

a Conditions: acetylene, $3.93 \mathrm{mmol}$; $\mathrm{NaBH}_{4} 7.9 \mathrm{mmol}$; catalyst, $0.01 \mathrm{mmol}(\mathrm{Mo})$; time, $3 \mathrm{~h}$; temperature, $30^{\circ} \mathrm{C}$; solvent, EtOH-THF ( $7.4: 4.6 \mathrm{ml})$. 
activity was found to depend on the content of mercaptomethyl groups in polystyrene and generally the polystyrene-supported catalysts were very active compared to the $\mathrm{PhCH}_{2} \mathrm{SH} / \mathrm{Mo}\left(\mathrm{NMe}_{2}\right)_{4}$ systems. The highest activity was observed for the molybdenum complex of polystyrene No. 2, which was the one most investigated in this work.

The simple calculation of the amount $(\%)$ of mercaptomethyl substitutions on phenyl rings of polystyrene and the average numbers of benzene rings surrounding one molybdenum metal in polystyrene-Mo complexes was carried out based on the results of the elemental analysis of sulfur and molybdenum atoms: $13.3 \%$ and 14.3 for polystyrene No. $1,9.23 \%$ and 20.0 for polystyrene No. 2, and $6.98 \%$ and 24.8 for polystyrene No. 3 .

A possible explanation for the highest activity of the polystyrene No. 2-Mo complex is as follows. A mononuclear Mo(III) species, which may be the real active species in the reduction of acetylene, is surrounded by $c a$. 20 phenyl rings of the polymer. The environment of the reactive Mo(III) species is thus in a hydrophobic domain, thus maintaining the catalytic activity and preventing the formation of catalytically inactive polynuclear Mo-Mo bonded species.

The effect of the addition of ferredoxin model complex, $\left[\mathrm{Fe}_{4} \mathrm{~S}_{4}(\mathrm{SPh})_{4}\right]^{2-}$, on the catalysis was also examined (Figure 4). A single component system of $\left[\mathrm{Fe}_{4} \mathrm{~S}_{4}(\mathrm{SPh})_{4}\right]^{2-}$ or PS-SH-molybdenum has only

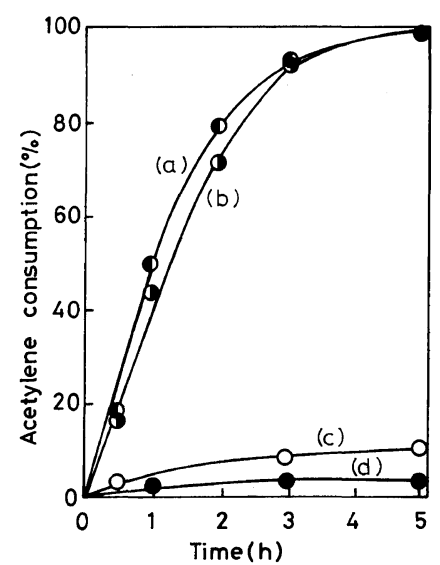

Figure 4. Effect of addition of $\left[\mathrm{Fe}_{4} \mathrm{~S}_{4}(\mathrm{SPh})_{4}\right]^{2-}$ on acetylene reduction by catalysis of polystyrene No. 2/ $\mathrm{Mo}\left(\mathrm{NMe}_{2}\right)_{4}$ system. Fe/Mo ratios: (a) 8 (O), (b) 4 (O), (c) 0 (O), and (d) $\left[\mathrm{Fe}_{4} \mathrm{~S}_{4}(\mathrm{SPh})_{4}\right]^{2-}$ only (O). Experimental conditions are the same as in Table II. very weak activity for the reduction of acetylene. By contrast, in a binary system of both compounds very high catalytic activity was observed, and an increase in the amount of $\left[\mathrm{Fe}_{4} \mathrm{~S}_{4}(\mathrm{SPh})_{4}\right]^{2-}$ caused an increase in the ethane formation (Table II). This indicates that the reaction products of the molybdenum complex with $\left[\mathrm{Fe}_{4} \mathrm{~S}_{4}(\mathrm{SPh})_{4}\right]^{2-}$ are the actual catalyst and/or that the cooperative functions between both complexes are very important in the reduction of acetylene. Actually, Otsuka et al. prepared an iron-molybdenum mixed cluster compound by the reaction of $\mathrm{Mo}(\mathrm{S}-t \mathrm{Bu})_{4}$ with a ferredoxin model compound. ${ }^{16}$ An investigation of the reaction products between the polystyrene-supported molybdenum(IV) and ferredoxin model compound by the spectroscopic method is now in progress.

In order to obtain information on the mechanism for the formation of ethane and butadiene, the total composition of the gaseous phase of the system was determined at certain time intervals (Figure 5). The results revealed that at the first stage the reduction of acetylene to ethylene takes place predominantly, followed by the reduction of ethylene to ethane, and also that butadiene is formed during the first 3 hours, but not after the complete reaction of acetylene. On the basis of these results, a plausible mechanism was proposed for the reduction of acetylene by the above polystyrene-supported molybdenum catalyst (Figure 6). The active species for the

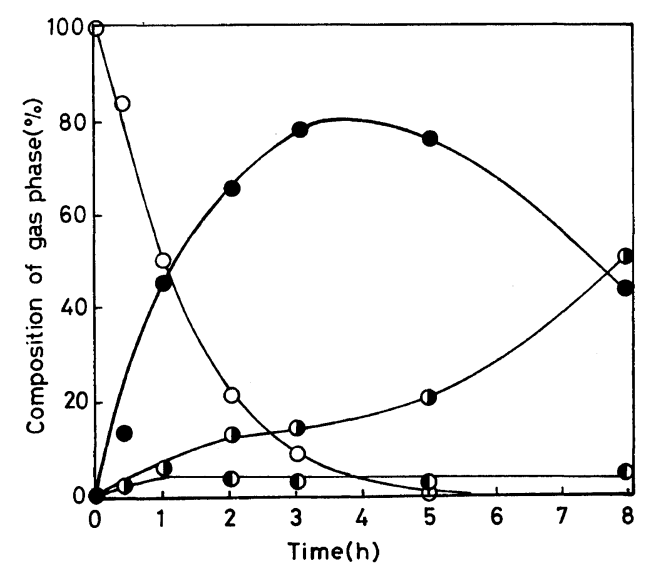

Figure 5. Change in gas phase concentrations of $\mathrm{C}_{2} \mathrm{H}_{2}$, $\mathrm{C}_{2} \mathrm{H}_{4}, \mathrm{C}_{2} \mathrm{H}_{6}$, and $\mathrm{C}_{4} \mathrm{H}_{6}$ in acetylene reduction with a binary system of polystyrene No. $2 / \mathrm{Mo}\left(\mathrm{NMe}_{2}\right)_{4}$ and $\left[\mathrm{Fe}_{4} \mathrm{~S}_{4}(\mathrm{SPh})_{4}\right]^{2-}(\mathrm{Fe} / \mathrm{Mo}=4) . \mathrm{C}_{2} \mathrm{H}_{2}(\mathrm{O}) ; \mathrm{C}_{2} \mathrm{H}_{4}(\mathrm{O})$; $\mathrm{C}_{2} \mathrm{H}_{6}(\mathrm{O}) ; \mathrm{C}_{4} \mathrm{H}_{6}(\mathrm{O})$. Experimental conditions are the same as in Table II. 


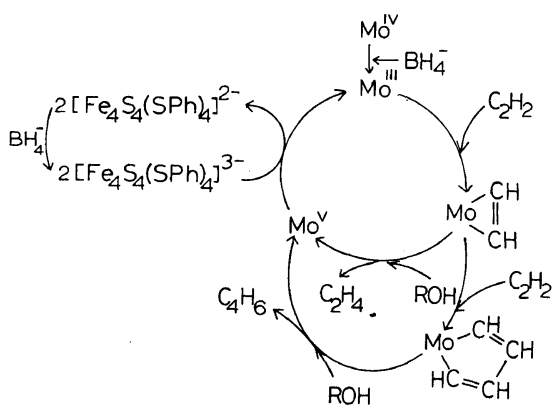

Figure 6. Proposed mechanism for acetylene reduction by catalysis of a binary system of molybdenum complex and $\left[\mathrm{Fe}_{4} \mathrm{~S}_{4}(\mathrm{SPh})_{4}\right]^{2-}$.

reduction of both acetylene and ethylene are presumably the same, possibly being the Mo(III) species with coordinative unsaturation although definitive evidence for the presence of the Mo(III) species has not been found. The formal oxidation number of molybdenum in the reduced state of native nitrogenase is unknown. Schrauzer et al. proposed a mechanism in which molybdenum(IV) species reacts with acetylene to give ethylene on hydrolysis and ethane is produced through the intermediacy of a $\left(\mu-\eta^{2}-\mathrm{C}_{2} \mathrm{H}_{2}\right.$-)molybdenum(IV) species. ${ }^{4}$ Molybdenum(IV) species are considered to serve as a two electron reducing agents. Schultz et $a l$. reported that the electrolytic reduction of a $\mathrm{Mo}(\mathrm{V})$-cysteine complex in the presence of acetylene gives a Mo(III)-acetylene complex. ${ }^{17} \mathrm{~A}$ Mo(III) species with coordinative unsaturation readily interacts probably with acetylene to give a "side-on $\left(\eta^{2}\right)$ " coordinated complex to afford ethylene on protonation by alcohol. The above $\eta^{2}$ acetylene intermediate then reacts with another molecule of acetylene to give the molybdenacyclo- pentadiene species which in turn gives butadiene by protonation with alcohol and then molybdenum is oxidized to $\mathrm{Mo}(\mathrm{V})$.

Finally, the efficiency of the polystyrenesupported Mo(IV) catalyst used in the reduction of acetylene was $c a .1 / 100$ of the nitrogenase (with $\mathrm{NaBH}_{4}$ as a reductant) and was one of the most active catalyst among the molybdenum complexes used up until now.

Reduction and Reductive Cleavage of Dinitrogen by Catalysis of a Mixed System of Mo(IV) Complexes and Ferredoxin Model Compound, $\left[\mathrm{Fe}_{4} \mathrm{~S}_{4}(\mathrm{SPh})_{4}\right]^{2-}$

Investigation of the reduction of dinitrogen as mimics of nitrogenase action have been primarily carried out the research groups of Shilov ${ }^{18}$ and Schrauzer. Very recently Schrauzer et al. reported the reduction of dinitrogen by catalysis of the in situ system of $\mathrm{MoO}_{4}^{2-}$ and insulin with $\mathrm{NaBH}_{4}$ at a catalyst concentration as low as $10^{-6} \mathrm{moll}^{-1} .^{7}$ This system gave ammonia in a good turnover number only for the initial short period, although the actual amount of ammonia determined was quite small. Some typical results on dinitrogen reduction are given in Table III. A binary system of the polystyrene-supported molybdenum(IV) and ferredoxin model compound had a higher activity than the cooresponding unsupported Mo(IV) system, thus being similar to the reduction of acetylene. The highest activity was observed in the system of random copolypeptide ${ }^{8}$ containing L-cysteine$\mathrm{Mo}\left(\mathrm{NMe}_{2}\right)_{4}$ and $\left[\mathrm{Fe}_{4} \mathrm{~S}_{4}(\mathrm{SPh})_{4}\right]^{2-}$. In all cases a small amount of hydrazine accompanied the production of ammonia. The results indicate that the Mo(IV) complexes investigated in this work had

Table III. Reduction and reductive cleavage of dinitrogen by catalysis of molybdenum(IV) complexes and $\left[\mathrm{Fe}_{4} \mathrm{~S}_{4}(\mathrm{SPh})_{4}\right]^{2-}$ with $\mathrm{NaBH}_{4}{ }^{\mathrm{a}}$

\begin{tabular}{|c|c|c|}
\hline \multirow{3}{*}{ Catalyst systems } & \multicolumn{2}{|c|}{ Product } \\
\hline & \multicolumn{2}{|c|}{$\mathrm{mol} / \mathrm{mol}[\mathrm{Mo}]$} \\
\hline & Hydrazine & Ammonia \\
\hline $\mathrm{Mo}\left(\mathrm{NMe}_{2}\right)_{4}+\left[\mathrm{Fe}_{4} \mathrm{~S}_{4}(\mathrm{SPh})_{4}\right]^{2-}$ & 0.004 & 0.007 \\
\hline Polystyrene No. $2 / \mathrm{Mo}\left(\mathrm{NMe}_{2}\right)_{4}+\left[\mathrm{Fe}_{4} \mathrm{~S}_{4}(\mathrm{SPh})_{4}\right]^{2-}$ & 0.013 & 0.15 \\
\hline Random copolypeptide $\left[(\text { Cys- } \gamma \text {-benzylglu } 6)_{4.5}\right] / \mathrm{Mo}\left(\mathrm{NMe}_{2}\right)_{4}+\left[\mathrm{Fe}_{4} \mathrm{~S}_{4}(\mathrm{SPh})_{4}\right]^{2-}$ & 0.004 & 0.37 \\
\hline
\end{tabular}

a Conditions: dinitrogen, $2000 \mathrm{ml}$; catalyst, $7.35 \times 10^{-5} \mathrm{~mol}(\mathrm{Mo})$; $\mathrm{NaBH}_{4}, 5.88 \times 10^{-3} \mathrm{~mol}$; solvent, THF-EtOH$\mathrm{MeOH}(16: 8: 8 \mathrm{ml})$; temperature, $30^{\circ} \mathrm{C}$; time, $24 \mathrm{~h} ; \mathrm{Fe} / \mathrm{Mo}$ ratio, 4 . 
weak activity in the reduction of dinitrogen, and shorter reaction time lowered the yield of ammonia. The present catalyst system seems to maintain catalytic activity for a longer period. This is a distinct advantage of the polymer-bound metal complex catalysts.

\section{REFERENCES}

1. S. P. Cramer, K. O. Hodgson, W. O. Gillum, and L. E. Mortenson, J. Am. Chem. Soc., 100, 3398 (1978).

2. S. P. Cramer, W. O. Gillum, K. O. Hodgson, L. E. Mortenson, E. O. Stiefel, J. R. Chisnell, W. J. Brill, and V. K. Shah, J. Am. Chem. Soc., 100, 3814 (1978).

3. V. K. Shah, J. R. Chisnell, and W. J. Brill, Biochem. Biophys. Res. Commun., 81, 232 (1978).

4. G. N. Schrauzer and P. A. Doemeny, J. Am. Chem. Soc., 93, 1608 (1971).

5. P. R. Robinson, E. L. Moorehead, B. J. Weathers, E. A. Ufkes, T. M. Vickrey, and G. N. Schrauzer, J. Am. Chem. Soc., 99, 3657 (1977).

6. G. N. Schrauzer, G. W. Kiefer, K. Tano, and P. A. Doemeny, J. Am. Chem. Soc., 96, 641 (1974).

7. B. J. Weathers, J. H. Grate, N. A. Strampach, and G. N. Schrauzer, J. Am. Chem. Soc., 101, 925 (1979).

8. N. Oguni, S. Shimazu, and A. Nakamura, Polym. J., 12, 891 (1980).

9. D. C. Bradley and M. H. Chisholm, J. Chem. Soc., Sect. A, 2741 (1971).

10. M. H. Chisholm, W. W. Reichert, and P. Thornton,
J. Am. Chem. Soc., 100, 2744 (1978).

11. R. Pribil and M. Malat, Collect. Czech. Chem. Commun., 15, 120 (1950).

12. "The clinical chemical analysis II" (Analytical Library vol. 3), The Japan Society for Chemical Analysis, Ed., Tokyo Kagaku Dojin, 1968, p 27 and p 463.

13. J. Hyde, L. Magin, and J. Zubieta, Chem. Commun., 204 (1980).

14. J. L. Corbin, N. Pariyadath, and E. I. Stiefel, J. Am. Chem. Soc., 98, 7862 (1977).

15. M. H. Chisholm, F. A. Cotton, B. A. Frenz, W. W. Reichert, L. W. Shive, and B. R. Stults, J. Am. Chem. Soc., 98, 4469 (1976); M. H. Chisholm, F. A. Cotton, C. A. Murillo, and W. W. Reichert, Inorg. Chem., 16, 1801 (1977).

16. S. Otsuka and M. Kamata, "Molybdenum Chemistry of Biological Significance," W. E. Newton and S. Otsuka, Ed., "Proceedings of the International Symposium," Lake Biwa, Kyoto, April 1979, Plenum Press, New York, N.Y., 1980, p 229.

17. D. A. Ledwith and F. A. Schultz, J. Am. Chem. Soc., 97, 6591 (1975).

18. N. T. Denisov, A. E. Shilov, N. I. Shuvalova, and T. P. Panova, React. Kinet. Catal. Lett., 2, 237 (1975).

19. R. H. Grubbs, C. Gibbons, L. C. Kroll, W. D. Bonds Jr., and C. H. Brubaker Jr., J. Am. Chem. Soc., 95, 2373 (1973).

20. J. Reed, P. Eisenberger, B-K. Teo, and B. M. Kincaid, J. Am. Chem. Soc., 100, 2375 (1978). 